\title{
KEBIJAKAN EKONOMI UMAR BIN KHATTAB
}

\author{
Oleh: \\ M. Aufarul Mawahib \\ Pengurus Pondok Pesantren Maslakul Huda Lamongan Jawa Timur \\ aufarulmawahib28@gmail.com
}

\begin{abstract}
Umar bin Khattab during his leadership in the city-state of Medina he had laid the foundations of the modern state especially in the economic field which will be discussed in this paper. Umar made many breakthroughs that had never been done by the Messenger of Allah and the Caliph before, Abu Baker as-Siddiq. Although one of the policies that will be mentioned in this paper is opposed by some Muslims at that time, Umar can prove to his people that what he did was for the common good and interests.
\end{abstract}

Keywords: Economic Policy, Umar Bin Khattab, Government

\begin{abstract}
ABSTRAK
Umar bin Khattab selama kepemimpinannya di negara kota Madinah ia telah meletakkan dasar-dasar kenegaraan yang modern khususnya dalam bidang ekonomi yang akan dibahas dalam makalah ini. Umar melakukan banyak trobosan yang belum pernah dilakukan oleh Rasulullah maupun khalifah sebelumnya, Abu Bakar as-Siddiq. Meski pada salah satu kebijakannya yang akan disinggung dalam makalah ini ditentang oleh sebagian kaum muslimin pada saat itu, namun Umar dapat membuktikan kepada rakyatnya bahwa apa yang dilakukannya adalah untuk kebaikan dan kepentingan bersama.
\end{abstract}

Kata Kunci: Kebijakan Ekonomi, Umar Bin Khattab, Pemerintahan

\section{PENDAHULUAN}

Kemajuan yang dicapai oleh sebuah negara untuk rakyatnya sudah tentu sebagian besar merupakan sumbangsih pemimpinnya yang lihai dalam memimpin dan mengelola negara. Berpengetahuan serta berlaku adil terhadap rakyatnya dan tidak semena-mena. Kepemimpinan yang adil akan mengutamakan kemaslahatan secara umum yang menyangkut kepentingan banyak orang.

Hal itu lah yang diajarkan oleh Rasulullah Saw. kepada umatnya. Meski Nabi Muhammad Saw. pernah bersabda "Dan engkau sekalian lebih mengetahui urusan-urusan duniamu", namun Islam dengan kesempurnaan ajarannya telah menanamkan nilai-nilai ketauhidan, keadilan, kesamaan, amanah ke dalam dada para sahabat Nabi Muhammad Saw yang berkontribusi besar dalam urusan bernegara yang notabene merupakan urusan keduniaan. Tidak terkecuali Umar bin Khattab (selanjutnya: Umar), Selama kepemimpinannya di negara kota Madinah ia telah meletakkan dasar-dasar kenegaraan yang modern khususnya dalam bidang ekonomi yang akan dibahas dalam makalah ini. Umar

${ }^{1} \mathrm{Wa}$ antum a'lamu bi amri dunyakum..hadis riwayat Bukhari No. 4358 
melakukan banyak trobosan yang belum pernah dilakukan oleh Rasulullah maupun khalifah sebelumnya, Abu Bakar as-Siddiq. Meski pada salah satu kebijakannya yang akan disinggung dalam makalah ini ditentang oleh sebagian kaum muslimin pada saat itu, namun Umar dapat membuktikan kepada rakyatnya bahwa apa yang dilakukannya adalah untuk kebaikan dan kepentingan bersama.

Dikarenakan Umar saat itu kapasistasnya sebagai kepala negara dan pemerintahan maka yang akan dibahas adalah kebijakan ekonomi makro. Pertanyaan mendasar dalam makalah ini yang sekaligus akan menjadi pembahasan adalah apa sajakah kebijakan Khalifah Umar dalam bidang ekonomi semasa ia menjadi pemimpin negara kota Madinah?

\section{PEMBAHASAN}

\section{Biografi Umar Bin Khattab}

Umar bin Khattab atau yang bernama lengkap Umar bin alKhattab bin Nufail bin Abd alUzza bin Rabbah bin Abdullah bin Qart bin Razah bin Adi bin Ka'ab bin Luai bin al-Adawi al-Quraish merupakan salah satu sahabat yang masih memiliki silsilah yang berkaian dengan garis keturunan Nabi Muhammad Saw yaitu pada generasi kedelapan. Umar merupakan cendikiawan atau satu dari tujuh belas orang Arab lainnya yang terpelajar pada masa itu. ${ }^{2}$ Sedangkan ibunya sendiri bernama Hantamah binti Hasyim bin Mughirah, dari Bani Makhzumi, di

${ }^{2}$ Nur Chamid, Jejak Langkah Sejarah Pemikiranb Ekonomi Islam, (Yogyakarta: Pustaka Pelajar, 2010), 68 mana Hantamah adalah saudara sepupu Abu Jahal. ${ }^{3}$

Umar sebelum masuk Islam adalah penantang keras agama yang dibawa Muhammad ini. Sama kerasnya dengan Abu Jahal. Sampai-sampai Rosul berdoa kepada Allah "Ya Allah muliakanlah Islam dengan salah satu dari dua orang yang lebih Engkau cintai; Umar bin Khattab atau Abu Jahal bin Hisyam". Dan Allah pun lebih memilih Umar yang akan menjadi umat yang membuat Islam mulia hingga akhir zaman.

Pasca tunduknya Umar ke dalam ajaran Islam membawa angin segar bagi umat Islam saat itu. Tidak heran menurut berbagai sumber masuknya Umar ke dalam agama kasih sayang ini disambut suka cita, selain umat Islam yang bertambah secara kuantiti tetapi juga diharapkan Islam semakin kuat karena telah masuk orang yang kuat, tegas dan keras yang cukup disegani di kota Makkah.

Perlu diketahui bahwa Umar dilahirkan 30 tahun sebelum masa kenabian Muhammad. Tentang sifat tegasnya itu tidak lain atas didikan sang ayah. Semasa kecil Umar diberikan tugas untuk menggembala kambing dan onta. Ia dididik dengan keras hingga Umar menjelma sebagai seorang yang tangguh dan tegas. ${ }^{4}$

Untuk sifat Umar sendiri beliau adalah sesosok pria yang

3Jaribah bin Ahmad Al-Haritsi, Alfigh al-Iqtishadi li amiril Mukminin Umar ibnu AlKhaththab, Terj, Asmuni Solihan Zamakhsyari, Fikih Ekonomi Umar bin Al-Khathab, Jakarta: Khalifa, 2010), 17

${ }^{4}$ Ibid., 18 
memiliki postur tubuh yang besar dan juga tinggi. Badannya ditumbuhi banyak bulu, rambut terurai dari kedua sisi kepalanya. Kulit Umar sendiri ada riwayat yang mengatakan putih kemerahmerahan dan ada yang mengatakan cokelat muda. Allah menghiasi wajah Umar dengan jenggot yang lebat dan berkumis yang tebal. Sedangkan untuk sifat jiwanya ia adalah seseorang yang adil, bertanggung jawab, sangat keras terhadap bawahannya dalam hal pengawasan agar tidak lalai menjalankan amanah rakyat, tegs, berwibawa dan banyakl manusia yang segan terhadapnya, memiliki firasat yang tajam, luas keilmuan dan cerdas dalam pemahamannya dan masih banyak sifat agung yang terpatri dan terpancar dalam diri umar. $^{5}$ Itulah sifat-sifat istimewa khalifah Umar di antara sifat-sifat khalifah yang lain seperti Abu Bakar, Usman dan Ali.

Bertahtanya Umar menjadi orang nomor satu di Madinah adalah atas pengangkatan yang dilakukan oleh Abu Bakar as-Siddik menjelang kematiannya. Tentunya setelah bermusyawarah dengan sahabat-sahabat yang lain. Dan hingga berakhir jabatannya sebagai $\mathrm{khalifah} \quad \mathrm{terhitung}$ kepemimpinannya di negara kota Madinah adalah kurun waktu 10 tahun 6 bulan atau lebih. Dan di masa itu Umar telah melakukan banyak hal-hal besar yang membawa Islam kepada masa kejayaanya yang khusus pada bidang ekonomi.

\section{Pengangkatan dan Masa Pemerintahan Umar bin Khattab}

Umar merupakan Khalifah kedua setelah Abu Bakar as-Siddiq setelah wafatnya Nabi Muhammad Saw. Pengangkatan Umar merupakan penunjukan langsung yang dilakukan oleh khalifah sebelumnya. Dengan demikian tidak ada calon lain selain Umar pada saat itu, dan terjadilah aklamasi yang dibarengi oleh persetujuan umat Islam pada saat itu. ${ }^{6}$ Maksudnya penunjukan langsung adalah hanya Umar yang diajukan oleh Abu Bakar, tidak ada calon lain. Dan setelah melalui musyawarah semua sahabat tidak ada yang keberatan dengan pengangkatan Umar. Dengan hanya satu calon maka terjadilah aklamasi seperti yang tertulis pada pembahasan sebelumnya. Dengan demikian Umar sepeninggalnya Abu Bakar as-Siddik telah resmi menjadi khalifah kedua yang akan meneruskan perjuangan Nabi Muhammad Saw.

Sesaat setelah Umar diangkat menjadi khalifah, beliau berpidato yang isisnya:" "Barang siapa ingin bertanya tentang alQuran datanglah pada Ubay bin Kaab. Barang siapa bertanya tentang ilmu faraid (ilmu waris) maka datanglah pada Zaid ibn Tsabit. Dan barangsiapa yang bertanya tentang harta, maka datanglah padaku. Karena Allah Swt telah menjadikanku sebagai penjaga dan pembagi harta".

${ }^{6}$ Nur Chamid, Jejak Langkah Sejarah Pemikiranb Ekonomi Islam, (Yogyakarta: Pustaka Pelajar, 2010), 68-69

${ }^{7}$ Ibid., 69-70 
Umar dalam pidatonya tersebut ingin menyempaikan bahwa untuk urusan harta serahkanlah kepadanya. Dalam hal ini Umar menjamin bahwa dirinya adalah seseorang yang amanah dan juga ahli dalam mengelola harta. Khususnya harta kekayaan Umat Islam (Negara Madinah) yang akan dikelolanya. Tidak salah bahwa banyak referensi mengatakan Umar tidak hanya alim dalam urusan agama, tetapi juga menjadi ahli dalam ilmu administrasi dan pemerintahan. Terlebih juga masalah ekonomi yang akan banyak terlihat pada kebijakannya nanti.

\section{Kebijakan Ekonomi Umar Bin Khattab}

Masa kepemimpinan Umar meski hanya 10 tahun lebih 6 bulan, namun telah banyak mengalami kemajuan. Bahkan kepemimpinan Umar adalah periode kepemimpinan yang sangat maju dapat dikatakan sebagai abad keemasan bagi umat Islam. ${ }^{8}$ Kepemimpinan Umar terlalu modern untuk zamannya. Di mana umar menetapkan kebijakan yang membuat Umat Islam menjadi sejahtera dan merasa tenteram. Umar juga melakukan ekspansi yang luas dan menyebarkan Islam dengan sangat masifnya.

Kepemimpinan Umar telah membawa kemajuan yang berarti bagi umat Islam khususnya bidang ekonomi. Umar telah berhasil menancapkan dan mengokohkan sistem ekonomi yang berlandaskan

\footnotetext{
${ }^{8}$ Ibid., 69
}

pada nilai keadilan dan kebersamaan. ${ }^{9}$

Tidak heran menurut Nurlaili Rahmawati, M.Ag ${ }^{10}$ menyebutkan beberapa kelebihan umar dalam memimpin diantaranya adalah Umar dianggap sebagai penggagas ilmu pemerintahan, karena seperti yang disampaikan sebelumnya saat pelantikan bahwa Umar sendiri pun mengakui bahwa dirinya sebagai orang yang ahli dalam bidang administratif. Selain itu Umar dalam memutuskan perkara hukum selalu berpegang teguh kepada al-Quran dan hadis. Salah satu kebijakan yang diterapkan oleh Umar yang dianggap modern itu adalah ketika umar melakukan penanganan urusan kekayaan negara di samping urusan pemerintahan. Umar paham sekali bahwa sebagai khalifah ia bertanggungjawab penuh terhadap rakyatnya di mana selain dilindungi, rakyat juga sebagai subjek yang menghasilkan kekayaan negara (melalui jizyah dan zakat) tetapi sekaligus juga menjadi objek bagi pembelanjaan negara Madinah pada saat itu yaitu melimpahkan keseluruhan harta negara untuk menjamin kesejahteraan rakyatnya. Tetapi beliau juga dikenal sebagai orang yang berani melakukan ijtihad selagi kemaslahatan umat Islam yang menjadi tujuannya.

Lebih lanjut dalam sambutannya ketika diangkat menjadi seorang pemimpin Umar

${ }^{9} \mathrm{M}$ Nur Rianto Al Arif, Ekonomi Islam Cet. 1 Ed. 1, (Tangerang Selatan: Universitas Terbuka, 2014), 2.10

${ }^{10}$ Nurlaili Rahmawati, "Kebijakan Ekonomi Umar Ibn Khattab", makalah, (Mataram, tt), 2 
menyampaikan beberapa kebijakan fiskal pada masa kepemimpinannya dengan 3 dasar:

a. Negara Islam mengambil kekayaan umum dengan benar, dan tidak mengambil hasil dari kharaj atau harta $f a^{\prime} i$ yang diberikan Allah kecuali dengan mekanisme yang benar.

b. Negara memberikan hak atas kekayaan umum, dan tidak ada pengeluaran kecuali sesuai dengan haknya dan negara menambahkan subsidi serta menutup utang.

c. Negara tidak menerima harta kekayaan dari hasil yang kotor. Seorang penguasa tidak mengambil harta umum kecuali seperti pemungutan harta anak yatim. Jika dia berkecukupan, dia tidak mendapat bagian apapun. Kalau dia membutuhkan maka dia memakai dengan jalan yang benar. $^{11}$

Untuk mewujudkan pemikirannya Umar bin Khattab mengeluarkan beberapa kebijakan yang menunjang terlaksananya pemikiran beliau, di antara yaitu:

\section{a. Reorganisasi Baitul Mal}

Setelah Abu Bakar
wafat dan ke-Khalifaan
diteruskan oleh Umar bin
khattab (13-23 H/ 634-644 M),
dalam ke-Khalifaannya banyak
kemajuan yang dialami oleh
ummat Islam. Cikal bakal
lembaga Baitul Maal yang telah
dicetuskan dan difungsikan
oleh Rasulullah SAW dan
diteruskan oleh Abu Bakar ash-
Sh id d i q, s e m a k i n
dikembangkan fungsinya pada

${ }^{11}$ Nur Chamid, Jejak Langkah..., 70 masa pemerintah khalifah Umar bin Khattab sehingga menjadi lembaga yang regular dan permanen. Pada tahun $16 \mathrm{H}$, bangunan lembaga baitulmaal pertama kali didirikan dengan Madinah sebagai pusatnya. Khalifah Umar melakukan reorganisasi Baitul maal dengan mendirikan Diwan Islam (DI) yang pertama disebut dengan alDiwan. Dimana al-diwan adalah Sebuah rumah khusus untuk menyimpan harta. Khalifah Umar juga mengangkat para penulisnya, menetapkan gajigaji dari harta Baitulmaal. Serta adanya pengeluaran dana pensiun bagi mereka yang bergabung dalam kemiliteran. Yang menarik, Baitul maal memiliki cabang-cabang disetiap ibu kota provinsi. Tiap cabang dan pusat memiliki buku induk yang mencatat segalanya. ${ }^{12}$

$$
\text { Berikut adalah }
$$

Klasifikasi Pendapatan Negara di Masa Pemerintahan Umar bin Khattab yang terhimpun dalam Baitul Mal. ${ }^{13}$

\begin{tabular}{|c|c|c|}
\hline No & $\begin{array}{c}\text { Jenis } \\
\text { Pendapatan }\end{array}$ & Tujuan Pengounaan \\
\hline 1 & Zakat dan & Pendapatan ini \\
& Ushr & didistribusikan dalam \\
& & tingkat lokal. Jika ada \\
& & ke- lebihan (surplus), \\
& & maka kelebihan itu di \\
& & kirim ke Baitul Maal \\
& & pusat (Madinah) dan \\
& & dibagikan kepada \\
& & delapan asnaf. \\
\hline
\end{tabular}

\footnotetext{
${ }^{12}$ Euis Amalia. "Sejarah Pemikiran Ekonomi Islam Dari Masa Klasik Hingga Kontemporer". (Depok: Gramata, 2010), 34

${ }^{13}$ Nur Chamid, Jejak Langkah..., 89
} 


\begin{tabular}{|c|c|c|}
\hline 2 & $\begin{array}{l}\text { Khums dan } \\
\text { Shadaqah }\end{array}$ & $\begin{array}{c}\text { Pendapatan ini } \\
\text { didistribusikan kepada } \\
\text { fakir-miskin atau untuk } \\
\text { membiayai mereka yang } \\
\text { sedang mencari } \\
\text { kesejahteraan, tanpa } \\
\text { diskriminasi apakah ia } \\
\text { seorang Muslim atau } \\
\text { bukan }\end{array}$ \\
\hline 3 & $\begin{array}{l}\text { Kharaj, Fai', } \\
\text { jizyah, Ushr } \\
\text { (pajak per- } \\
\text { dagangan), } \\
\text { dan sewa } \\
\text { tanah }\end{array}$ & $\begin{array}{c}\text { Pendapatan ini } \\
\text { digunakan untuk } \\
\text { membayar dana } \\
\text { pensiun dan dana } \\
\text { bantuan serta untuk } \\
\text { menutupi biaya } \\
\text { operasional } \\
\text { administrasi, kebutuhan } \\
\text { militer dan sebagainya. }\end{array}$ \\
\hline 4 & $\begin{array}{l}\text { Pendapatan } \\
\text { lain- lain }\end{array}$ & $\begin{array}{c}\text { Pendapatan ini } \\
\text { digunakan untuk } \\
\text { membayar para pekerja, } \\
\text { pemeliharaan anak-anak } \\
\text { terlantar, dan dana } \\
\text { sosial lainnya. }\end{array}$ \\
\hline & \multicolumn{2}{|c|}{$\begin{array}{l}\text { Umar juga membuat } \\
\text { ketentuan bahwa pihak } \\
\text { eksekutif tidak boleh turut } \\
\text { campur dalam mengelola harta } \\
\text { Baitulmaal. di tingkat provinsi, } \\
\text { pejabat yang bertanggung jawab } \\
\text { terhadap harta ummat tidak } \\
\text { bergantung pada gubernur dan } \\
\text { mereka mempunyai otoritas } \\
\text { penuh dalam melaksanakan } \\
\text { tugasnya serta bertanggung } \\
\text { jawab langsung kepada } \\
\text { pemerintah pusat. }{ }^{14}\end{array}$} \\
\hline
\end{tabular}

b. Diberlakukannya sistem cadangan darurat

Diberlakukannya sistem cadangan darurat, di mana dari sumber penerimaan yang ada tidak langsung didistribusikan seluruhnya. Hal ini untuk membiayai angkatan perang dan kebutuhan darurat untuk umat. Kebijakan seperti ini berbeda dengan kondisi ketika zaman khalifah abu bakar, sebagaimana yang dijelaskan oleh Ibn Katsir dalam kitab al-Bidayah $W$ an Nihayah:

"Sewaktu Abu Bakar wafat dan Umar bin Khaththab menjadi Khalifah, bejiau mengumpulkan para bendaharawan kemudian masuk ke rumah Abu Bakar dan membuka Baitul Maal. Ternyata mereka tak menemukan apa pun (dalam riwayat Iain disebutkan banya mendapatkean satu dinar saja yang terjatub dari kantungnya). "15

\section{c. Pemerintah bertanggung} jawab terhadap jaminan sosial warga negaranya.

Untuk merealisasikan terwujudnya kesejahteraan warganya melalui jaminan sosisal, khalifah umar menunjuk Aqil bin Abi Thalib, Mahzamah bin Naufal, dan Jabir bin Mut'im yang tergabung dalam komite Nassab, dimana komite ini bertugas untuk membuat sensus penduduk sesuai tingkat kepentingannya dan golongannya. Kemudian disusun berdasarkan tingkatan sebagai berikut: ${ }^{16}$

1) Orang-orang yang mempunyai hubungan kekerabatan dengan Nabi Muhammad SAW

${ }^{15}$ Nur Chamid, Jejak Langkah....75

${ }^{16}$ Adimarman Azwar Karim, Sejarah Pemikiran Ekonomi Islam, (Jakarta: Rajawali Press, 2014), 62-63 
2) Para sahabat yang ikut perang badar dan uhud

3) Para imigran ke Abysiniah dan Madinah

4) Para pejuang perang qadisiyah atau orang yang menghadiri perjanjian hudaibiyah,

5) Kaum wanita, anak-anak, dan para budak, dst

$$
\text { Yang mana dari }
$$

golongan-golongan tersebut Jumlah tunjangannya berbedabeda sesuai tingkatan kepentingan dan golongannya. Namun secara umum jumlah tunjangan yang dikeluarkan setiap tahun adalah sebagai berikut: ${ }^{17}$

\begin{tabular}{|c|c|c|}
\hline No & Penerima & Jumlah \\
\hline 1. & $\begin{array}{l}\text { Aisyah dan } \\
\text { Abbas ibn } \\
\text { Abdul } \\
\text { Mutholib }\end{array}$ & $\begin{array}{l}\text { Masing-masing } \\
12.000 \text { dirham }\end{array}$ \\
\hline 2. & $\begin{array}{l}\text { Istri-istri Nabi } \\
\text { selain Aisyah }\end{array}$ & $\begin{array}{l}\text { Masing-masing } \\
10.000 \text { dirham }\end{array}$ \\
\hline 3. & $\begin{array}{c}\text { Ali, Hasan, } \\
\text { Hussain, dan } \\
\text { para pejuang } \\
\text { Badar }\end{array}$ & $\begin{array}{c}\text { Masing-masing } \\
5.000 \text { dirham }\end{array}$ \\
\hline 4. & $\begin{array}{c}\text { Mantan } \\
\text { pejuang Uhud } \\
\text { dan para } \\
\text { migran ke } \\
\text { Abyssinia }\end{array}$ & $\begin{array}{c}\text { Masing-masing } \\
4.000 \text { dirham }\end{array}$ \\
\hline 5. & $\begin{array}{c}\text { Kaum } \\
\text { Mubajirin } \\
\text { sebelum } \\
\text { Fathul Makeab }\end{array}$ & $\begin{array}{c}\text { Masing-masing } \\
3.000 \text { dirham }\end{array}$ \\
\hline 6. & $\begin{array}{c}\text { Anak mantan } \\
\text { pejuang Badar } \\
\text { (yang } \\
\text { memeluk } \\
\text { Islam saat } \\
\text { Mekkah }\end{array}$ & $\begin{array}{l}\text { Masing-masing } \\
2.000 \text { dirham }\end{array}$ \\
\hline
\end{tabular}

${ }^{17}$ Ibid., 63

\begin{tabular}{|c|}
\hline ditaklukkan); \\
anak Mubajirin \\
dan Anshor; \\
yang ikut \\
dalam perang \\
Qadisyya, \\
Uballa; dan \\
yang hadir \\
dalam sumpah \\
Hudaibiyah
\end{tabular}

Orang-orang Mekkah tunjangan 800 dirham. Warga Madinah 25 dinar, Muslim di Yaman, Syiria, dan Iraq 200 sampai 300 dirham, anak yang baru lahir dan yang tidak diakui masing-masing 100 dirbam. Tambahan pensiun untuk kaum Muslim adalah gandum, minyak, madu, dan cuka dalam jumlah tetap. Kuantitas dan jenis barang berbeda-beda di setiap wilayah. ${ }^{18}$

Kebijakan khalifah Umar bin Khattab ini sangat mensejahterakan umat Islam ketika itu, dan berdasarkan pendapat para ulama, merupakan pemerintahan yang pertama kali menjamin kesejahteraan warganya. Namun di balik kemanfaatan dari kebijakan ini, terdapat kekurangan di dalamnya, dimana beberapa masyarakat yang tergantung dari pemberian jaminan pemerintah, melalaikan usahanya, sehingga tidak produktif. Hal itu sebenarnya telah diketahui oleh khalifah umar, dan beliau merencakan perbaikan kebijakan tersebut agar kembali ke tujuan asalnya

${ }^{18}$ Ibid., 63 
untuk mensejahterakan umat, bukan membuat umat menjadi bergantung dari pemberian, tapi beliau sebelum mewujudkan rencananya, beliau wafat.

\section{d. Diverifikasi terhadap objek zakat}

Diverifikasi terhadap objek zakat, yaitu pembaruan terhadap objek yang dikenakan sebagai objek zakat yang baru. Dalam bahasa fiskal saat ini biasa dikenal dengan ekstensifikasi sumber-sumber penerimaan negara.

\section{Pada zaman khalifah}

Umar berkuasa, kondisi ekonomi masyarakat arab mengalami banyak perubahan, yang mana ketika zaman khalifah Umar, mayoritas masyarakatnya sejahtera. Kemudian ketika zaman Khalifah umar berkuasa, banyak kegiatan yang produktif, namun belum terdapat ketentuan zakat sebelumnya, seperti peternakan dan perdagangan kuda, yang mana ketika zaman Khalifah Umar, kuda memilik harga jual yang tinggi dan banyak digemari, bahkan sebuah riwayat menerangkan bahwa harga kuda arab taghlabi diperkirakan bernilai 20.000 dirham dan orang-orang Islam terlibat dalam perdagangannya, namun belum terdapat kewajiban zakatnya. $^{19}$

Kemudian karena maraknya perdagangan kuda tersebut, maka khalifah umar menetapkan zakatnya sebesar

${ }^{19}$ Ibid., 69 satu dinar atau atas dasar ad valorem, seperti satu dirham untuk setiap empat puluh dirham. Selain kuda yang baru ditetapkan zakatnya ketika zaman khalifah Umar, terdapat pula barang lainnya, yaitu karet, hasil laut dan peternakan lebah. ${ }^{20}$

\section{e. Pengembangan ushr (pajak) pertanian.}

Sebelum Islam datang, setiap suku atau kelompok suku yang tinggal di pedesaan biasa membayar pajak (ushr) pembelian dan penjualan (Maqs). Besarnya 10 persen dari nilai barang atau satu dirham setiap transaksi. Tetapi setelah negara Islam berdiri di negara Arabia, "Nabi mengambil inisiatif untuk mendorong usaha perdagangan dengan menghapus bea masuk antar propinsi yang masuk dalam daerah kekuasaan dan masuk dalam perjanjian yang ditandatangani oleh beliau bersama suku-suku yang tunduk kepada kekuasaannya. Secara jelas dikatakan bahwa pembebanan sepersepuluh hasil pertanian kepada pedagang Manbij (Hierapolis) dikatakan sebagai yang pertama dalam masa Umar." 21

Orang-orang Manbij adalah orang-orang Harbi, yang meminta izin kepada Khalifah untuk masuk ke negara Muslim untuk melakukan perdagangan dengan membayar sepersepuluh dari nilai barang. Setelah

\footnotetext{
Pemikiran...., 69

${ }^{20}$ Adimarman Azwar Karim, Sejarah ${ }^{21}$ Ibid., 70
} 
konsultasi dengan teman-teman dekatnya, izin diberikan. Tetapi kasus khusus, ketika Abu Musa al-Ashari, menulis surat kepada Umar bahwa pedagang Muslim dikenakan pajak sepersepuluh di tanah Harbi, Umar menyarankan untuk membalasnya dengan mengenakan pajak pembelian dan penjualan yang normal kepada mereka. Ada perbedaan versi mengenai tingkat ukurannya. Tingkat ukuran yang paling umum adalah dua setengah persen untuk pedagang Muslim, lima persen untuk Kafir Zhimmi dan sepuluh persen untuk Kafir Harbi, dengan anggapan nilai barang melebihi dua ratus dirham. Menurut Ziyad Bin Hudayr, seorang Ashir (pengumpul ushr) di Jembatan Euphrate mengatakan, "kita biasanya mengumpulkan ushr dari pedagang Roma saja". Lebih lanjut dia menjelaskan bahwa Kafir Harbi yang tinggal di negara Islam selama periode enam bulan atau kurang dikenai sepuluh persen; bila memperpanjang masa tinggal hingga satu tahun mereka dikenakan pajak sebesar lima persen. ${ }^{22}$

Ushr dikumpulkan dari barang-barang sekali setahun. Seorang Taghlibi menjual kudanya dengan harga sebesar 20.000 dirbam, Staf Zaid memintanya untuk membayar seribu dirbam (5\%) sebagai ushr. Jumlah tersebut dibayarkan tetapi kuda tersebut tidak terjual sehingga ia mengambil kembali kudanya. Setelah beberapa waktu ia datang kembali dengan kudanya dan pemungut pajak kembali meminta ushr darinya. Orang tersebut menolak membayar apapun dan mengadukan masalahnya kepada Khalifah Umar. Setelah mendengarkan kasusnya, $\quad$ U mar menginstruksikan para pejabat untuk tidak menarik ushr dua kali dalam setahun walaupun barang tersebut diperbaharui. ${ }^{23}$

Pos pengumpulan ushr berbeda-beda termasuk di Ibu Kota. Menurut Saib Yazid, pengumpul ushr di pasar-pasar Madinah, nabatean yang berdagang di Madinah juga dikenakan pajak pada tingkat yang umum, tetapi setelah beberapa waktu, Umar menurun- kan presentasinya menjadi lima persen untuk minyak dan gandum. Hal ini dilakukan untuk mendorong impor barang-barang tersebut di kota. ${ }^{24}$

\section{f. Undang-undang perubahan pemilikan tanah (land reform)}

Und a n g- und a n g perubahan pemilikan tanah (land reform), yaitu di mana tanah-tanah yang tidak produktif dikuasai negara untuk diolah oleh masyarakat dan masyarakat membayar kharaj atas tanah yang diolah tersebut. Hal ini berkaitan dengan semakin luasnya wilayah kekuasaan Islam.

${ }^{24}$ Ibid.., 72 
Ketika daerah kekuasaan Islam semakin luas, maka terjadi perbedaan apakah tanah itu di bagikan kepada para pejuang, ataukah menjadi kekuasaan negara. Dan dalam kepemimpinan Khalifah Umar, tanah tersebut tidak dibagibagikan ke umat Islam, melainkan di serahkan ke penduduk aslinya untuk mengelolanya, namun dengan syarat mereka harus membayar kharaj dan jizyah. Khalifah umar beralasan bahwa wilayah tersebut sangatlah luas, dan bila dibagi-bagikan, dikhawatirkan akan timbul praktek tuan tanah, yang mana hal itu merugikan masyarakat. ${ }^{25}$

Khalifah Umar juga melarang bangsa arab untuk menjadi petani karena meraka bukan ahlinya. Menurut beliau, tindakan memberi lahan pertanian kepada orang yang bukan ahlinya adalah sama dengan perampasan hak-hak publik. Khalifah Umar juga menegaskan, bahwa negara berhak untuk mengambil alih tanah yang tidak di manfaatkan pemiliknya dengan memberikan ganti rugi secukupnya. ${ }^{26}$

$$
\text { Dalam masalah }
$$

kepemilikan tanah, khalifah Umar bin Khattab menerapkan beberapa peraturan sebagai berikut:

1) Wilayah Iraq yang ditaklukkan dengan kekuatan, menjadi Muslim dan kepemilikan ini tidak dapat diganggu gugat, sedangkan bagian yang

${ }^{25}$ Ibid., 66

${ }^{26}$ Ibid., 67 berada di bawah perjanjian damai tetap dimiliki oleh pemilik sebelumnya dan kepemilikan tersebut dapat dialihkan.

2) Kharaj dibebankan pada semua tanah yang berada di bawah ka- tegori pertama, meskipun pemilik tersebut kemudian memeluk Islam. Dengan demikian tanah seperti itu tidak dapat dikonversikan menjadi tanah ushr.

3) Bekas pemilik tanah diberi hak kepemilikan, sepanjang SB membayar kharaj dan jizya.

4) Sisa tanah yang tidak ditempati atau ditanami (tanah mati) atau tanah yang diklaim kembali (seperti Basra) bila ditanami oleh Muslim diberlakukan sebagai ushr.

5) Di Sawad, kharaj dibebankan sebasar satu dirham dan satu rafiz. (satu ukuran lokal) gandum dan barley (jenis gandum), dengan anggapan tanah tersebut dapat dilalui air. Harga yang lebih tinggi dikenakan kepada ratbah (rempah atau cengkeh) dan perkebunan.

6) Di Mesir, menurut sebuah perjanjian Amar, dibebankan dua dinar, bahkan hingga tiga Irdabb gandum, dua qist untuk setiap minyak, cuka, dan madu, dan rancangan ini telah disetujui Khalifah.

7) Perjanjian Damaskus (Syiria) menetapkan pembayaran tunai, pembagaian tanah dengan Muslim. Beban per-kepala 
sebesar satu dinar dan beban jarib (unit berat) yang diproduksi per jarib (ukuran) tanah. $^{27}$

g. Perbaikan jalan umum, terutama jalan yang ramai dilalui untuk para pedagang dan masyarakat umum.

Jalan merupakan aspek yang sangat menunjang perekonomian suatu Negara, karena jalan memudahkan sesorang untuk mengakses daerah-daerah yang jauh menjadi dekat dan mudah di jangkau. Ketika zaman khalifah Umar bin Khattab beranggapan bahwa jalan merupakan sarana untuk memudahkan mobilisasi dan peredaran-peredaran unsur produksi, dan menghubungkan antar pasar, serta sebagai tempat peredaran hasil produksi.

Diriwayatkan oleh beberapa referensi, bahwa umar bin khattab memerintahkan gubernur mesir 'Amr bin Ash untuk menggali terusan yang menghubungkan laut merah dengan sungai nil sehingga kapal bisa berlabuh di al-jar, dimana hal tersebut memudahkan transportasi laut antara hijaz dan mesir. Di pelabuhan al-jar, khalifah umar juga memerintahkan untuk membangun gudang yang digunakan untuk menyimpan makanan dan hal-hal lain yang dating dari mesir yang disebut dengan Dar al Rizqi, yang kemudian menunjuk Sa'ad Al Jari sebagai penanggung

${ }^{27}$ Adimarman Azwar Karim, Sejarah Pemikiran...., 67-68 jawabnya serta pelabuhan aljar. $^{28}$

\section{PENUTUP}

Kebijakan ekonomi Umar bin Khattab pada masanya sangatlah modern, hal ini terlihat pada yang membuat Umat Islam menjadi sejahtera dan merasa tenteram. Umar juga melakukan ekspansi yang luas dan menyebarkan Islam dengan sangat masifnya, sehingga dalam memutuskan perkara hukum selalu berpegang teguh kepada al-Quran dan hadis. Salah satu kebijakan yang diterapkan oleh Umar yang dianggap modern itu adalah ketika umar melakukan penanganan urusan kekayaan negara di samping urusan pemerintahan. Umar paham sekali bahwa sebagai khalifah ia bertanggungjawab penuh terhadap rakyatnya di mana selain dilindungi, rakyat juga sebagai subjek yang menghasilkan kekayaan negara (melalui jizyah dan zakat) tetapi sekaligus juga menjadi objek bagi pembelanjaan negara Madinah pada saat itu yaitu melimpahkan keseluruhan harta negara untuk menjamin kesejahteraan rakyatnya.

\section{DAFTAR PUSTAKA}

Al Arif, M Nur Rianto, 2014, Ekonomi Islam Cet. $1 \mathrm{Ed}$. 1, Tangerang Selatan: Universitas Terbuka.

Amalia, Euis, 2010, Sejarah Pemikiran Ekonomi Islam Dari Masa Klasik. Hingga Kontemporer. Depok: Gramata.

Chamid, Nur, 2010, Jejak Langkah Sejarah Pemikiranb Ekonomi Islam, Yogyakarta: Pustaka Pelajar.

${ }^{28}$ Jaribah bin Ahmad Al-Haritsi, Fikih Ekonomi Umar...., 514-515 
Jaribah bin Ahmad Al-Haritsi, 2010, Al-fiqh al-Iqtishadi li amiril Mukminin Umar ibnu AlKhaththab, Terj, Asmuni Solihan Zamakhsyari, Fikih Ekonomi Umar bin Al-Khathab, Jakarta: Khalifa.

Karim, Adimarman Azwar, 2014, Sejarah Pemikiran Ekonomi Islam, Jakarta: Rajawali Press.

Rahmawati, Nurlaili, "Kebijakan Ekonomi Umar Ibn Khattab", makalah, Mataram. 